\title{
PROCESS OF IMPLEMENTATION AND BENEFITS OF CRIME SCENE INVESTIGATION IN CASE OF CRIMINAL INVESTIGATION IN INDONESIA
}

\author{
Sri Endah Wahyuningsih \\ endah.w@unissula.ac.id \\ Faculty of Law, Universitas Islam Sultan Agung (UNISSULA), Semarang, Indonesia \\ Teguh Prasetya \\ teguhprasetya@yahoo.com \\ Master of Law Science, Universitas Islam Sultan Agung, Semarang, Indonesia \\ Muchamad Iksan \\ mi214@ums.ac.id \\ Faculty of Law, Universitas Muhammadiyah Surakarta, Indonesia
}

\begin{abstract}
The case of crime scene conducted by the investigator is the main part in the disclosure of criminal case because in the crime scene can be found the interaction between the perpetrator of the crime, the evidence used and the witness/victim of crime at the time of the criminal event. Therefore this paper analyzes the implementation process and the benefits of crime scene in the process of criminal investigation in Indonesia. The research method used was sociological juridical, with primary and secondary data sources. Primary data were obtained by conducting interviews with respondents, they were investigators who investigate criminal case. The results of the research on the procedures for the implementation of the Crime Scene Investigation is started from the preparation of the crime scene, the trip to the scene, the first action at the crime scene (TPTKP). The crime scene investigation covers the general observations, photography, sketching, evidence collection, victim handling, and perpetrators of crime scene organization, and the end of the crime scene, which consists of consolidation, opening/exempting the crime scene, the making of investigation report at the scene, and the evacuation of activities. The benefit of crime scene investigation in criminal investigation is as evidence, source of information to look for witness, as source to look for evidence and as saber to find perpetrator, legal basis of investigator in execution of crime scene is JUKLAK (standard operational procedure) Police of Republic of Indonesia with number 04/1982 and JUKNIS Police of the Republic of Indonesia with the number JUKNIS 01/11/1982.
\end{abstract}

Keywords: Crime Scene Investigation, Criminal, Implementation.

\section{A. INTRODUCTION}

In the process of criminal justice

in Indonesia, the role of the investigator is very important because he/she must reveal the actual case incident to seek material truth as the purpose of criminal procedure law ${ }^{1}$. As investigators, the police have a role to conduct

1 Sri Endah Wahyuningsih, 2017, "PERANAN DIGITAL EVIDENCE SEBAGAI ALAT BUKTI." 1(1): 169-86. 
investigations, namely a series of investigative actions in respect of and according to the manner laid down in the Act to seek and collect evidence which with such evidence makes the light of the offense committed and in order to find the suspect ${ }^{2}$.

Therefore, in handling the crime scene in order to find and collect the evidence in crime scene, the investigator must also be based on the prevailing laws and regulations as Article 7 paragraph (1) Law No.8 Year 1981 on the Book of Law of the Criminal Procedure Code, the investigator has the authority:

a. To receive a report or complaint from a person about a crime;

b. To take the first action in the crime scene;

c. To stop a suspect and to check the suspect's identity;

d. To make arrests, detentions, searches and seizures;

e. To conduct examination and confiscation of mail;

f. To take fingerprints and take pictures of people;

2 Jan Collie, 2018, "Digital Forensic Evidence Flaws in the Criminal Justice System." Forensic Science International 289: 154-55. https://doi.org/10.1016/j.forsciint.2018.05.014 g. To call people to be heard and examined as suspects or witnesses;

h. To bring in the necessary experts in connection with the examination of the case;

i. To hold a suspension of investigation;

j. To take other actions under responsible law.

Article 111 of the Criminal Procedure Code states that:

1. In the event of being caught in the hands of everyone is entitled, while every person who has authority in the duty of public order, peace and public security shall arrest the suspect to be submitted with or without evidence to the investigator or investigator.

2. Upon receipt of the surrender of the suspect as referred to in paragraph (1) the investigator shall immediately perform the examination and other actions in the framework of the investigation.

3. Investigators who have received such reports coming immediately to the scene may prohibit anyone from leaving the place during the 
above examination not yet completed.

4. Offenders of such a prohibition may be forced to remain there until such examination is completed.

Basically, all activities in the legal process of settlement of criminal cases, since the investigation until the final decision is pronounced before the court by the panel of judges is in the form of activities related to the proof or activities to prove.3 Although criminal prosecution is focused on the evidentiary processes in court, the process actually proves that it has been established and started from the moment of the investigation. In fact, at the time of investigation, a preliminary work in running the process of criminal cases is done by the State. ${ }^{4}$

In carrying out duties as an initial action, the investigators, if a criminal event occurs, will carry out the handling of the crime scene in order to find and collect evidence

3 Jehle, Jörg Martin, Paul Smit, and Josef Zila, 2008, "The Public Prosecutor as Key-Player: Prosecutorial Case-Ending Decisions." European Journal on Criminal Policy and Research 14(23): 161-79.

4 Sri Endah Wahyuningsih, Noor Adi, and Muchamad Iksan, 2018, "The Role of Scientific Testimony in the Process of Investigation of Crime in Indonesia.": 97-103. existing in the place of the case according to the prevailing laws and regulations.

The crime scene is the main part of the base of the disclosure of a criminal case because in the crime scene can be found the interaction between the perpetrator (suspect) the evidence used and the witness/victim of the crime, at the time of the criminal event, it is part of the investigation stage. ${ }^{5}$ The crime scene is closely related to the police line as a boundary mark to avoid any change of circumstances after the occurrence of a crime or offense. Considering the importance of the handling of the crime scene, the initial action of the investigator should keep the crime scene undamaged or changed by the police line. .

In practice the handling of crime scene by the investigator always involves various elements such as technical elements Sabhara, Reskrim,

5 Eeden, Claire A J Van Den, Christianne J De Poot, and Peter J Van Koppen. 2016. "Science and Justice Forensic Expectations: Investigating a Crime Scene with Prior Information." Science \& Justice 56(6): 475-81. http://dx.doi.org/10.1016/j.scijus.2016.08.003.

6 Adderley, Richard, Michael Townsley, and John Bond. 2007. "Use of Data Mining Techniques to Model Crime Scene Investigator Performance." 20: $170-76$. 
and Identification. In addition, community participation is necessary because people around the crime scene often change or even damage the case because of the curiosity of the community for what is happening around them.

Based on the explanation, this study aims to analyze the function of police lines in the process of investigating criminal acts to help locate and find evidence so as to make light of a crime.

\section{B. DISCUSSION}

\section{Understanding The Police Line}

The police line or so-called safety band is the limit on the Crime Scene (TKP) which is marked with a yellow ribbon that is placed around the crime scene (TKP). The Police Line serves to maintain the status quo which means to secure or disinfect the Crime Scene (TKP) so that there is no change, addition, or improvement.(Scaffold hopping Molecular crime scene investigation dusting for fingerprints 2013)

The definition of the status quo in the police force is a place of Crime Scene (TKP) which is still in its original state as the original and unchanging state. The status quo actually comes from the Latin phrase "statu quo". In general, the notion of the status quo is circumstances that are fixed remain unchanged as they are now or as before.

The crime scene status quo is a genuine crime scene (TKP) condition as it was during the actors, or shortly after the perpetrator acted and left the scene. The status quo is important because it is where the police initially get the guidance and illustration of how a crime occurs and how the perpetrator perpetrates his crime. It is mandatory for anyone, especially members of the Police who first went to the scene to secure the crime scene until the identification officer/crime scene officer came ${ }^{7}$. In general, security of crime scene is by installing police line at crime scene and area around crime scene which allows for the discovery of evidence. Besides aiming to secure the crime scene, the police line installation also aims to banish the masses from clustered at the scene.

7 Eeden, Claire A J Van Den, Christianne J De Poot, and Peter J Van Koppen. 2016. "Science and Justice Forensic Expectations: Investigating a Crime Scene with Prior Information." Science \& Justice 56(6): 475-81. http://dx.doi.org/10.1016/j.scijus.2016.08.003. 
2. Police line procedure in the process of criminal

\section{investigation in Indonesia.}

One of the investigation activities is the processing of the Crime Scene (TKP). The crime scene processing is related to the investigation process because the crime scene processing is part of the investigation process.

The activities in the processing of the scene include 8:

1. Seek and collect information, instructions, evidence, suspect's identity, and witness / victim for further investigation;

2. Seeking relation between witness / victim, suspect, and evidence; and

3. To obtain a description of the modus operandi of the criminal offense;

Other provisions governing the crime scene are the Regulation of the Chief of Police of the Republic of Indonesia Number 6 Year 2010 concerning Investigation

Management by Civil Servant Investigator.

In order to process the crime scene, the actions taken by PPNS are as follows: a. Seek information, clue, evidence and identity of the suspect and victim or witness for the purpose of further investigation; and

b. The search, retrieval, collection, and safeguard of evidence, conducted by certain methods or technical assistance of investigations such as forensic laboratories, identification, forensic medicine, and other fields of expertise.

The security precautions at the crime scene are done by closing and securing the crime scene (maintaining the status quo) by creating a police line at the scene of the crime scene when possible, or creating a crime scene marker based on the results of the coordinate point retrieval.

In addition, the Field Guide is also mentioned about the stages of action at the scene of the crime scene, among others: do shooting with a view to perpetuate the scene of including the presence of witnesses, activities/mining activities and evidence at the scene and to provide a clear picture of the scene and condition of the scene and to 
help complete the deficiencies in the processing of the scene including deficiencies in recording and sketching, overall scene crime scenes and various angles, details or close-ups of each object required for investigation; and sketching the scene. The sketch is made with the intention to describe the scene as thoroughly as possible and as a material to describe the scene of the scene at the time of the crime scene.

According to AKP. Edi Sutrisno, $\mathrm{SH}$, as Kasatreskrim Polres Pekalongan City, the legal basis in the standard operational procedures handling and processing the crime scene (TKP), namely:

a. Law No. 8/1981 on the Criminal Procedure Code

b. Law No. 2 of 2002 on the National Police of the Republic of Indonesia

c. Regulation of Chief of Police No. 14 Year 2012 About Management of Crime Investigation ${ }^{10}$

In preparation to carry out the handling and processing of the crime scene (TKP) conducted by

10 Interview with AKP. Edi Sutrisno, $\mathrm{SH}$, as Kasatreskrim Polres Pekalongan city, 23 January 2018
Satreskrim Police Resort Pekalongan City is as follows. First prepare the team members of Crime Scene Investigation ie investigators/investigators helper who has good moral, meticulous, tenacious and meticulous, has technical skills and tactics of crime scene processing, responsiveness and responsive attitude, mastering legislation and other knowledge, communicative and humanist in performing their duties, mastering procedures for handling and processing of cases and able to work in teams.. In addition it also prepares facilities and infrastructure consisting of:

1. Police Line

2. Bag Kit

3. Compass

4. Gloves

5. Distance meter (meter)

6. Photographer

7. Firearms, handcuffs, knives/scissors

8. Ropes, chalk, labels and lacquers

9. Packing material such as evidence

a. Brown cover paper

b. Plastic bags of various sizes 
c. Plastic tube of various sizes

d. Envelopes, PPPK equipment

10. Notebooks, papers and stationery for sketching

11. Other equipment deemed necessary to be adapted to the scene of the crime scene and the type of criminal case that occurred

12.GPS (Global Positioning System)

13. Oil fuel sonding tool

After all the preparation is complete the process will be implemented in the crime scene.

\section{Procedures for the} Implementation of Crime Scene Investigation (TKP) by Investigators on Crime at the Pekalongan City Police

Crime Scene is a place where criminal offense and in the surrounding environment found evidence and traces of crime, because there is no crime that does not leave a trace, for that in exposing a crime police officers must know where and how to start activities,. Every investigator in conducting the crime scene activity still refers to the implementation guidelines (JUKLAK) of the Police of the Republic of Indonesia with Perkap No. 14 of 2012 About Management of Investigation of Criminal which contains as follows:

a) The correct and professional crime scene processing (TKP) in accordance with the order in which the procedures that have been adapted to JUKLAK and JUKNIS.

b) General Observations

c) Shooting public

d) Shoot close-up of the findings at the scene

e) Collection of evidence relating to crime scene carefully and correctly

f) Perform a crime scene that aims to narrow the unit of investigation unit if the crime scene to solve the case and find the perpetrator

g) Find witness information that really understand about the criminal event

h) Interrogating victims, perpetrators and their families. 
i) Immediately make an
inspection report (BAP).

Implementation of Crime Scene

on Criminal event at Police Resort of Pekalongan City based on interview with Kaur Ident Aiptu Sukardi regarding some criminal case happened in Pekalongan City, done with 2 (two) action, they are:

1) Handling the crime scene by conducting the First Action at the crime scene (TPTKP), which is the action to be taken immediately to provide assistance or protection to the victim, closure and security of the crime scene for further investigation.

2) Processing the crime scene, which is action or activity after the first action to seek, collect, evaluate, analyze the instructions, information and evidence and the identity of the suspect, in order to give direction to further investigation ${ }^{11}$.

From the handling of the crime scene, the investigator is informed of the time of the crime, the place of the crime, the proceedings of the crime, the motive or the reason for the commission of the crime, and the consequences caused by the crime.

11 Aiptu Sukardi, 2018
The sequence of handling and processing the Crime Scene are:

1) Preparing for the crime scene

Before coming to the scene of the case, the police prepare personnel and facilities/equipment adequate or in accordance with the situation and condition of the case to be faced. Preparation is divided into 3 (three) fields, namely:

a. The first field of personnel consisting of elements PAMAPTA, RESCRIM, BANTEK such as labkrim (criminal laboratory), identification and forensic medicine.

b. Second, the field of transport and communications that prepare communication tools and transportation tools for speed of action and control and control relations with the parent unity.

c. Third, the main equipment field and RESCRIM prepare the equipment deemed necessary by adjusting to the scene of the crime scene that occurred.

2) On the way to the Place of Crime Scene

Police coming to the Place of Crime Scene must be from 
different directions, this is done because the police might catch a runaway suspect. At the time of coming to the crime scene, the police do it in two ways, namely:

a. By demonstrative means (wearing sirens),

b. And in a tacit manner.

3) First Action in Crime Scene is to help victims, protect victims, safeguard and closure of the Crime scene by maintaining the status quo, which is like installing a police line that serves to prohibit anyone from entering the scene except the investigator or other police officers, and make the boundary of the Crime Scene with the aim that the authenticity of the Crime Scene is maintained for further investigation. In the First Action at Crime Scene (TPTKP), the investigator obtained triangular evidence. If done in the crime scene, the next action is as follows: Improving the closure and security of the crime scene (retained the status quo) by requesting the help of other elements Samapta, conducting searches and seizing the items found from Suspects, securing Suspects/perpetrators, securing evidence at the scene and installing police lines, separating Suspects and witnesses at the scene of the crime in order not to influence each other, making it difficult to obtain actual information (Objective), seeking, collecting witnesses and notices his/her identity and instructs him to remain on the premises (s) to be asked for his statement, on behalf of the Head of the Local Unit as the Investigator, create and sign the request of Visum et Repertum, making a rough sketch of the crime scene and prepare the report and the Minutes of Examination at Crime scene and close and secure crime scene, maintain status quo (original position) and when necessary with the help of other Samapta elements.

Based on the evidence of this triangle resulted in the discovery of traces, among others: First, From victims, perpetrators, tools used at the scene. Second, the perpetrator, the crime scene and the tools used on the victim, Third, From the victim, the crime scene and the tool used on the victim and the Fourth, From the victim, 
the crime scene and the perpetrator on the tool used

4) Case Place Event

The crime scene investigation (TKP) is an action on activities after the first action at the crime scene (TPTKP), with the intent to seek, collect, evaluate, analyze, clarify, explanation and evidence as well as the identity of the suspect in theory "triangular evidence "In order to give direction to the next investigation. The sequence of the implementation of Crime Scene which is based on the technical guidance of the Police of the Republic of Indonesia concerning the handling of crime scene (TKP) mentioned as follows:

a) General observation

Police make general observations by referring to things or objects such as the entrance of the perpetrator, the tools used or abandoned by the offender, paying attention to the signs of resistance or violence, noting the peculiarities found in the Place of Crime Scene and its surroundings.

b) Photographing
Shooting or taking pictures is conducted with the intent to immortalize the situation or circumstance of the Place of Crime Scene including victims and other evidence at the time found and provide a real picture of the situation and condition of the crime scene.

c) Sketching

Sketching is used to describe the situation of the crime scene as accurately as possible and for the reconstruction of the Future crime scene if necessary Evidence Collection is required. One of the actions performed by officers at the Place of Evaluation is to look for evidence. There are several methods in searching for evidence. The first method uses the spiral method. It is some of the officers of the Pekalongan City Police Officer move hand in hand with a certain distance, following the spiral shape rotate inward. The second method used is the double strip method (Strip and double method), 3 officers side by side with a certain distance, moving together 
simultaneously from the wide side to the other side of the scene, and can rotate towards the original. The third method uses the Zone Method. It is the way the area is divided into several parts to investigate. The fourth method, using the Wheel method in this case, place or room is considered as a circle, the way is that some officers move together towards the outside starting from the midpoint of the scene to carry out the handling of objective evidence of dead evidence or physical evidence found in the crime scene and the handling of subjective evidence of testimony from witnesses and suspects, the manner of the police handling that is first, direct inquire or interviews of persons suspected of seeing, hearing, knowing the crime can be obtained from the community located around the scene to help provide information.

d) Handling of Victims, Witnesses, and Actors. The handling of the victim in the case of the criminal act of premeditated murder, the investigator performs with several stages as follows: Photographing of the corpse according to its location and position is done in general or close-up done from various directions with aimed at the suspicious body part, researching and securing related evidence with the ongoing criminal offense. Utilizing technical assistance of doctors who are brought in by asking several things: First Duration / length of death based on observation of death signs such as stiff corpses (If there is a criminal act of murder). Provide a line mark on the position of the corpse (If there is a crime of murder). After fingerprints are taken immediately sent to the hospital to request Visum Et Repertum.

Handling of Witnesses In this case, the investigator performs 4 (four) ways, namely: conducting interviews, classifying as witnesses and/or suspected suspects, conducting a brief examination of witnesses and suspected 
persons, and conducting an examination of the victim, the victim's circumstances, the victim's attitudes or being taken to a hospital/specialist doctor for a VER (Visum et repertum) request.

Handling the perpetrator, the action by the investigator against the perpetrator is done by 3 (three) ways, namely the investigator conducts the arrest, searches the body and safeguards, investigates and secures the evidence contained in the perpetrator and the investigator conducts a brief examination to obtain temporary information on matters associated with events.

e) Crime Event Organizing, In Organizing Crime TKP, for simple crime scene processing is only done by one or two police officers only, while a large crime scene is needed a special.

5) End of Handling Place of Crime Scene

a) Consolidation is a checking activity on personnel, equipment and all things known/found at the scene. a) The opening/exemption of the crime scene, conducted by Pamapta after receiving notice from the investigator that the crime scene has been completed.

b) In the case of the crime scene workers either from the detective or from technical assistance (identification, labfor and dokfor) still takes time for processing the scene.

c) The making of the minutes of examination at the crime scene, made by the investigator or auxiliary investigator conducting the processing of the crime scene in the form of: the results found at the scene of the case, the action taken by the officer against the results found at the scene of the case, as material for implementation and development of subsequent investigations, and as an evaluation of superiors. In addition to the investigation report at the scene of the crime scene, the investigator also makes an announcement of the Discovery and Seizure of evidence at the scene of the 
crime scene, the discovery and retrieval of the scene at the scene of the crime scene, the Minutes of entering at the scene of the crime scene, the Minutes of Shooting at the scene and the Minutes according to the acts do.

d) Evacuation of activities in evacuation activities the investigator may do so specifically to certain places of incidence requiring the handling of the future crime scene, because the nature and quality of the handling and processing of the crime scene is considered high so it is necessary to evacuate the activities that have been done.

\section{The Benefits of Crime Scene in} the Process of Investigation of Criminal Offenses in Indonesia.

Basically, in the criminal investigation of a crime, there are several techniques or activities, among others, investigation, examination and settlement and submission of case files. ${ }^{12}$

Other marks and other items of evidence are meticulously searched, which are found to be photographed and recorded, where and how they are found, collected, in neat wrap and given notes as necessary so as not to be confused and to be easily known, if necessary, to be sealed.. The search, collection, storage, delivery, traces and evidence must be thoroughly worked out according to prescribed scientific techniques, do not act recklessly to avoid all sorts of mistakes, therefore the value of truth from physical evidence to can be trusted depending on the procedure:

1. how the invention,

2. how to take it,

3. how to collect,

4. how to wrap it,

5. how to send it to laboratory,

6. how to check in laboratory and

7. how to store before the case on trial.

In relation to the foregoing matters, it is necessary for the

${ }^{12}$ Sri Endah Wahyuningsih, Noor Adi, and Muchamad Iksan. 2018. "The Role of Scientific Testimony in the Process of Investigation of Crime in Indonesia." : 97-103. 
authors to state that the facts of truth such as the statements and evidence which may have been collected by the investigator or auxiliary investigator in their attempt to obtain sufficient evidence. Therefore, after the facts of truth such as evidence have accumulated, he begins to devise various possibilities to describe the crime and the attempt to find the perpetrator. For that the investigator and/or aid investigator must have a certain fantasy power, in the sense of having a creative and logical mind, because he must be able to understand the consequences of something deed, circumstances and events can understand also the causes of action, circumstances and events that ${ }^{13}$.

Furthermore, in brief, all proceeds of processing at the scene of the crime are all seen, heard and recovered and all actions taken by the investigator and/or auxiliary investigator at the scene of the case, immediately set

13 Devi, Renuka, Nicole Richetelli, Jeff B Pelz, and Jacqueline A Speir. 2017. "Eye Tracking to Evaluate Evidence Recognition in Crime Scene Investigations." Forensic Science International 280: 64-80. https://doi.org/10.1016/j.forsciint.2017.08.012. forth in a Minutes of Examination (BAP) in its broad line contains general matters covering the date of making the minutes, the officers handling the crime scene, the source of the reports and the tasks performed.

The results found at the crime scene should contain the general situation of the crime scene (TKP in the broad sense) ie whether a crime scene in the form of houses, public places, warehouses or open spaces etc., the boundaries of the scene means whether the scene is a house that is fenced, with whatever the house is adjacent and the weather conditions of crime scene means for example when the scene was visited by the sunny weather, but the humid soil is suspected due to rain in the evening and so forth. It also contains the Special Situation of the crime scene (TKP in the narrow sense), which consists of the scene of crime scene, the decomposition of the scene of the crime scene in a closer view, the location or position of the victim as accurately described.

The actions taken should be what and who committed the 
crime. If the first action mentioned above is perfected note the activity and who is doing. For completeness of Minutes, there are attachments, among others:

a. Sketch of crime scene made on millimeter paper.

b. Photo albums shoot the scene of the scene (just a portrait of portraits of a crime scene posted on folio paper with complete shooting data).

c. In the case of the scene of the death of a victim, it is recommended to sketch the circumstances of the victim ${ }^{14}$.

Regarding the minutes of the event, the investigator involved makes the BAP (official report). This is in accordance with the provisions of Article 8 of the Criminal Procedure Code (1) which reads "The Investigator shall prepare an official report on the implementation of the action referred to in Article 75 without prejudice to the other provisions of this law." While Article 75 of the Criminal Procedure Code is:

14 Sri Endah Wahyuningsih, Risto Samodra, and Dwi Wahyono. "THE IMPLEMENTATION OF RESTORATIVE JUSTICE IN THE TRAFFIC CRIME INVESTIGATION PROCEDURES IN." 97(24): 97-109.
1) Minutes of Events shall be made for each action concerning:

a. Inspection of the suspect;

b. Arrest;

c. Detention;

d. Search;

e. Home income;

f. Confiscation of objects; $g$

g. Examination of mail;

h. Examination of witnesses;

i. Examination of Place of Case Event;

j. Implementation of court decisions and decisions;

k. The implementation of other actions in accordance with the provisions of this law.

2) Official Report shall be made by the relevant official in performing such action in paragraph (1) and shall be contained in the oath of office.

3) The minutes of the event other than signed by the official referred to in paragraph (2) shall also be signed by all parties involved in the action referred to in paragraph (1).

The things described above is that if the examination at the scene can achieve satisfactory results, in the sense of getting 
enough evidence, it is easy to reveal a criminal act that occurred. Because with the processing of a good scene or carefully will be easy to reveal a case as a whole. If the crime scene is damaged or difficult to ascertain then the course of the investigation will also experience obstacles because the scene is the first step of the investigation process.

On the basis of the above description, it is clear that the crime scenes are very useful as stated by BAUR Brigadier Yonanta Arya that "the usefulness of the crime scene is very important considering the scene will be found important explanations or buinevidence that needs to be processed in revealing the case. The use is limited to investigation activities in the process of investigation.. "Furthermore the use of a crime scene as it is said is: "That TKP (crime scene) is useful in the criminal investigation heading, because the scene can be used:

1. As a proof;

2. Sources of information for finding witnesses;
3. As a source to search for evidence

4. As a saber to find the perpetrator ${ }^{15}$

Hence, the crime scene is absolutely necessary, because with the goods and evidence collected at the scene, the investigator made the first step to uncover a case. From here, it can be said that the crime scene has usefulness as a place that can provide clues about a criminal acts that happened. In other words, it can also be mentioned that the use of crime scene is as one source of information and important evidence that must be processed in an effort to reveal the crime that occurred. The scene of the case is the key to the solution, in an effort to disclose a criminal act and as a first step of a crime disclosure activity, so the crime scene value in an effort to reveal a crime is not in doubt. The scene of the crime in addition to presenting objective evidence (dead object) as a result of changes in the natural environment caused by a crime, also presents subjective evidence in the form of witness statements, 
as well as other information necessary for investigative activities to reveals a crime.

\section{CONCLUSION}

The procedures for the execution of the crime scene begins with the preparation for the crime scene, the trip to the scene, the first action at Crime Scene (TPTKP), the crime scene which consists of general observations, photographs, sketches, evidence collection, victim handling, witnesses and perpetrators organizing the crime scene, and the end of the crime scene, which consists of consolidation, opening/exempting the crime scene, the making of investigation report at the scene, and the evacuation of activities. Benefits by the crime scene in the criminal investigation offices are the key to solving cases in an attempt to disclose a criminal offense because it reveals objective evidence (object of inanimate object) and subjective evidence in the form of witness testimony and other information. The function of the crime scene is basically to obtain evidence, source of information to look for witnesses, as a source to search for evidence and as a saber to find the perpetrator, the legal basis of the investigator in the implementation of crime scene is JUKLAK Police of the Republic of Indonesia with number 04/1/1982 and JUKNIS Police of the Republic of Indonesia with JUKNIS number 01/11/1982. 


\section{BIBILIOGAPHY}

\section{Books:}

Adderley, Richard, Michael Townsley, and John Bond. 2007. "Use of Data Mining

Techniques to Model Crime Scene Investigator Performance." 20: 170-76.

Collie, Jan. 2018. "Digital Forensic Evidence - Flaws in the Criminal Justice System."

Forensic Science International 289: 154-55.

https://doi.org/10.1016/j.forsciint.2018.05.014.

Devi, Renuka, Nicole Richetelli, Jeff B Pelz, and Jacqueline A Speir. 2017. "Eye Tracking to

Evaluate Evidence Recognition in Crime Scene Investigations." Forensic Science

Internationa/280: 64-80. https://doi.org/10.1016/j.forsciint.2017.08.012.

Eeden, Claire A J Van Den, Christianne J De Poot, and Peter J Van Koppen. 2016. "Science

and Justice Forensic Expectations : Investigating a Crime Scene with Prior

Information." Science \& Justice 56(6): 475-81.

http://dx.doi.org/10.1016/j.scijus.2016.08.003.

Jehle, Jörg Martin, Paul Smit, and Josef Zila. 2008. "The Public Prosecutor as Key-Player:

Prosecutorial Case-Ending Decisions." European Journal on Criminal Policy and

Research 14(2-3): 161-79.

"Scaffold Hopping Molecular Crime Scene Investigation - Dusting for Fingerprints." 2013. : 491-98.

Wahyuningsih, Sri Endah. 2017. "PERANAN DIGITAL EVIDENCE SEBAGAI ALAT BUKTI." 1(1): 169-86.

—. "Reconstruction of the Retroactive Principle in the Indonesian Criminal Law Code

Based on the Value of Religious Wisdom." I(1): 177-98.

Wahyuningsih, Sri Endah, Noor Adi, and Muchamad Iksan. 2018. "The Role of Scientific

Testimony in the Process of Investigation of Crime in Indonesia." : 97-103.

Wahyuningsih, Sri Endah, Risto Samodra, and Dwi Wahyono. "THE IMPLEMENTATION OF

RESTORATIVE JUSTICE IN THE TRAFFIC CRIME INVESTIGATION PROCEDURES IN." 97(24): 97-109.

Interview with AKP. Edi Sutrisno, SH, as Kasatreskrim Polres Pekalongan city, 23 January 2018.

Interview with Iptu Joyo Suharto, SH, investigator of Polres Pekalongan City, 20 January 2018. 
Interview with Brigadir Yonanta Arya, the investigator of Polres Pekalongan City, 24 January 2018

Article 24 letter a Perkapolri No.14 / 2012 